\title{
Towards optimization of entomopathogenic nematodes for more service in the biological control of insect pests
}

\author{
Mahfouz M. M. Abd-Elgawad(1)
}

\begin{abstract}
Cost and reliability have hindered entomopathogenic nematodes (EPNs) from realizing their full market size. Research approaches continually evolve in response to these issues. They address EPN basics, but other issues are less recognized among masses working on these biocontrol agents. So, this review emphasizes on the due but less recognized roles to optimize EPN research and get better findings in nematode realm. Being almost impossible for nematologists to act united, they need to use standardized procedures which allow future reviews to be analytical and may build on them. Current atypical sampling procedures of EPNs may lead to erratic results. Comparable sampling may better enable grasping the interaction between EPN distribution and agricultural management to develop more swiftly field application techniques and can introduce EPNs' populations to a more even distribution designed to enhance their efficacy. Functional sampling should be expanded. Furthermore, EPNs should be included in integrated pest management programs in ways that make them complimentary or superior to chemical pesticides. Further modeling of EPNs' populations should be tried. The few transgenic methods applied in EPNs should be followed up to address non-stability of selected beneficial traits and markers of beneficial genes. Awareness-raising of more growers, cooperatives, and extensions of EPNs as bio-insecticides for both plant and livestock pests should be attempted in earnest via broad and deep training. We should better communicate and apply the positive trends and standardization in EPNs' research. Required but less known services to optimize research in the nematode realm should further be addressed.
\end{abstract}

Keywords: Entomopathogenic nematodes, Biological control, Recognized roles, Sampling

\section{Background}

The basics of entomopathogenic nematology such as biology, taxonomy, mutualism, and use for agricultural pest control have recently been well reviewed and updated by several authors in Campos-Herrera (2015) and Abd-Elgawad et al. (2017). Entomopathogenic nematodes (EPNs) contain two families: Steinernematidae, represented by the genera Steinernema and Neosteinernema, and Heterorhabditidae, represented by the genus Heterorhabditis. Their life cycle is unique involving a symbiotic relationship with pathogenic bacteria in the genus Xenorhabdus for Steinernema and Photorhabdus

Correspondence: mahfouzian2000@yahoo.com

Plant Pathology Department, National Research Centre, El-Behooth St., Dokki, Giza 12622, Egypt

Springer Open for Heterorhabditis. The bacteria are carried by the only soil-dwelling free-living stage: the third/infective stage juveniles (IJs). After finding a suitable insect host, these IJs must enter the host hemocoel for successful infection to occur. EPNs enter the insect host via natural body openings or by penetrating the cuticle, release the bacteria into the insect hemocoel, and resume development. The bacteria replicate rapidly and kill the insect host often within 12-48 h. On releasing the bacteria, the IJs feed on the symbiont biomass and insect tissues metabolized by the bacteria in order to develop. Thus, the bacteria must provide conditions within the cadaver that will support nematode growth and development. The IJs of Steinernema exist as amphimictic males and females, so that both a male and a female must infect the host 
hemocoel to mate and reproduce inside the insect. On the contrary, the IJs of Heterorhabditis develop into hermaphroditic females and subsequently into amphimictic males and females, heterogenic life cycle. Therefore, infection of the host by a single IJ of hermaphroditic Heterorhabditis can reproduce inside the insect hemocoel. Nematode reproduction continues within the host until resources in the cadaver are depleted, usually allowing for two to three generations. If the food supply is limited, the nematode eggs produced by the first generation develop directly into infective juveniles. IJs exit from the host searching for new hosts to infect. Eventually, the non-feeding IJs of Heterorhabditis and Steinernema are adapted for survival, dispersal, host finding, and infection. As biocontrol agents, the EPNs have advantages such as movement ability, high virulence, ability to kill hosts quickly, easy mass rearing, high reproductive potential, broad host range, and safety to vertebrates, plants, and many other non-target organisms (Kaya and Gaugler 1993).

In addition to such ideal attributes of EPNs as biocontrol agents, continuous improvements in different aspects of their commercial applications are in progress. Examples are in their formulation and delivery technology and mass-production efficiency along with the isolation of new efficacious species/strains (Shapiro-Ilan et al., 2014a; Abd-Elgawad et al. 2017; Lulamba et al. 2018 and Shehata et al. 2019). In this respect, the desirability of reducing hazardous pesticide usage have been accounting for developing their commercial applications. The nematodes have been commercially utilized for control of scarab larvae in lawns and turf, fungus gnats in mushroom production, invasive mole crickets in lawn and turf, black vine weevil in nursery plants, and Diaprepes root weevil in citrus (Lacey and Georgis, 2012). Scientists are still boosting EPNs forward to occupy new positions. For example, based on identifying recent conditions and practices that enhance the economic and effective use of EPNs for pest management, a feasible and cost-effective EPN-application method for integrated pest management (IPM) of Caribfly, Anastrepha suspensa, to improve guava production was developed (Heve et al. 2018). In this IPM program, profitability of guava production in south Florida will not be very sensitive to marginal costs of the spot treatment method, when compared to the field-wide broadcasting of Heterorhabditis bacteriophora.

On the other hand, EPNs have recently demonstrated promise to control other groups of pests such as the gray flesh flies Parasarcophaga aegyptiaca as one of the external parasites, which have veterinary importance not only due to their wide distribution but also because of their role in causing serious diseases, such as myiasis, which can invade various tissues of man and animals, leading to serious consequences. Also, the soft tick Argas (persicargas) persicus has a veterinary importance as it serves as vector of several animal diseases including Anaplasma, Babesia, Cowdria, Ehrlichia, and Theileria. Both pests are susceptible to EPNs with virulence variations that may be exploited for economic control (ElSadawy et al. 2018). Likewise, the hard tick Hyalomma dromedarii, a serious pest and a vector for diseases of camels in Egypt, is a good host for EPN (El-Sadawy et al. 2008a, b). Such a relatively neglected specialty requires more sound EPNs' research to control animal pests and maintain animal health via safe and environmentally friendly methods.

Nevertheless, apparent successful control of many insect pests by EPNs frequently has not led to occupy an important position in the pesticide market for such pests. In fact, four issues affect the use of EPNs. These are high price, limited product demand, insufficient knowledge of the end user, and low efficiency (Askary et al. 2017). These factors are fairly interrelated, e.g., low efficiency may lead to a limited product demand whereas effective-cost application may adversely affect EPNs' efficiency. Many researchers are tackling these problems via trying to find novel or genetically manipulating nematode strains so that they are longer lived and/or resistant to environmental stresses such as desiccation, ultraviolet radiation, and temperature extremes. Also, they utilize different application strategies, such as spraying nematodes just around the base of plants, putting them in "tea bags" as a slow release system, or dipping seedling roots into EPN suspensions (Askary et al. 2017). The result would presumably mean fewer nematodes used at a consequently lower cost but with a good level of protection against insect pests. Other promising avenues to expand EPN commercial applications include fitting EPNs into existing or emerging IPM strategies. Therefore, opportunities that facilitate incorporation into crop management systems should be seized, such as developing new (compatible) application methods or leveraging synergies between EPNs and other pest management tactics (Koppenhöfer and Grewal, 2005; Shapiro-Ilan et al. 2014a and 2017 and Abd-Elgawad 2017a, b). In order to optimize their benefits, EPNs can be included in IPM programs in ways that make them complimentary or superior to chemical nematode management methods (Stevens and Lewis, 2017). Therefore, intensive research is ongoing to further explore where bio-insecticides can act synergistically or additively with other agricultural inputs in IPM programs (Laznik et al. 2012; Laznik and Trdan 2014, 2017 and Bajc et al. 2017). Clearly, the combined use of EPNs and other pesticides should be practiced on a wider basis. Definitely, EPNs have a place of their own as safe-bio-insecticides but we need them for more pest control approaches. This is 
especially important, since there are other insecticides which are or are likely to become widely available soon. Hence, identification of research priorities for harnessing EPNs in sustainable agriculture in the context of grasping their relevant ecology, biology, mode of action, and interaction with other agricultural inputs is desperately needed. Needless to remind that research toward reducing EPN product costs, increasing its availability, and improving its efficacy and carryover effect will stimulate wider use of EPNs in biocontrol. Moreover, fostering EPN usage does not include development of new target pests only but also employment of novel approaches for applying the symbiotic bacteria of EPNs or their metabolites or byproducts as control materials for arthropod pests and plant pathogens (e.g., Ffrench-Constant et al. 2007; Da Silva et al. 2013; Shapiro-Ilan et al. 2014b; Abd-Elgawad 2017c and El-Sadawy et al. 2018).

All the above-mentioned lines of thinking are substantial to seize more significant share in the pesticide market at developed countries, while feasible introduction of sound EPNs application in developing countries. Therefore, more innovative thinking, systematic experiments, and well-designed field trials examining new options and showing their worth are desperately needed. This is especially timely towards optimization of EPNs for more service in the biological control of insect pests. In this regard, a few techniques for carefully conceived experimentations are desperately needed. These techniques are less known among masses interpreting and/or benefiting from the results of EPNs' research in general. Thus, due roles which are stressing heavily on the conscience of scientists trying to optimize EPNs' research and get better findings in nematode realm will be presented and discussed herein.

\section{Functional sampling}

A hypothesis of getting a high recovery frequency value of samples positive for EPNs is based on four pillars, i.e., favorable sampling method, time and site targeted, and extraction technique used should be tested. Such a functional sampling may aim at timely centering on recovering EPNs' populations of areas with the targeted pests. For the first pillar, random, stratified random, and systematic samplings are three main methods that can be used for EPNs' isolation. Contrary to stratified random samples, random ones suffer from the possibility that samples may chance to target an unimportant range so that most soil-dwelling EPNs remain unsampled. Systematic samples also endure the possibility that the sample spacing may coincide with a periodic variation in the targeted EPNs' populations and thereby go undetected (Taylor 1999). Stratified random sampling is better than the other two methods in getting more samples positive for EPNs. With large-scale random or systematic sampling, the percentage of samples positive for EPNs was frequently lower than $35 \%$ as reported by several authors in Abd-Elgawad et al. (2017). These results are valid given the intent to make widely geographic and representative sampling. On the contrary, functional sampling is intended to choose the appropriate method, timing, site, and technique to extract EPNs adapted to control specific pest(s). So, they require a season of host abundance, a directed and specific search of environments in which the EPNs will have had to develop the desired trait, and optimum EPN-sampling method and extraction technique. For the second pillar, repeated baiting per sample could back the abovementioned hypothesis, study the spatial variability of IJs over the baiting cycles, and distinguish differential persistence among EPNs' populations. Briefly, more baiting cycles could result in more nematode-positive samples (e.g., Abd-Elgawad 2014). Needless to remind that such cycles may also reveal the degree of the EPN spatial heterogeneity, which is considered a fundamental aspect of the population biology of these species and has important ramifications for their population dynamics, population genetics, and community structure. A third element is to choose an appropriate sampling time. According to the target of a researcher, factors such as environmental conditions, season of host abundance, or relevant climate to the intended insect host may be good options to choose from. For example, the peak reproduction season of most insect pests is always in the summer in Egypt, where the temperature rises. Finally, the targeted site should be wisely selected. Most EPNs are not used against their original host or habitat, but the longstanding recognition that natural enemies are closely associated with their hosts/host-habitats is still forming a solid scientific basis. This rule is materialized in Steinernema scapterisci, which was isolated from parasitized mole crickets in Uruguay (Nguyen and Smart 1990) and is used for their effective control (Stevens and Lewis 2017). Also, S. silvaticum was found only, and valid to application, in acidic $(\mathrm{pH}<4.5)$ environments (Dzięgielewska and Skwiercz 2018). Thus, an adequate trap insect species, other than the commonly used greater wax moth (Galleria mellonella L.) or mealworms (Tenebrio molitor) larvae, should be used if the candidate species was targeted for control because some species/strains can be host-specific. Clearly, more than one baiting cycle may enable us to use different and separate species of baiting insects in each cycle. Identifying the best host matching of these isolates, especially for the soil-dwelling development stages of such insects, should be attempted in earnest.

Nevertheless, functional sampling does not negate the fact that large-scale sampling is valid given the intent to make widely geographic and representative sampling. 
Therefore, functional sampling should be expanded in parallel to wide EPNs' surveys for coordination in search of new species/strains. In this way, the potential use of EPNs, which is focused on inundatively applied augmentative biological control agents, may be more expanded to both classical and conservation biocontrol. Given many insect pests in such areas, all factors which affect EPNs' treatment efficacy below- (Stuart et al. 2006, 2015) and above-ground (Arthurs et al. 2004 and Hussaini 2017) should be carefully considered in experimentation, especially for those interested in which species of EPNs are found in specific sites. Moreover, most surveys have merely assessed the EPNs' occurrence in single soil samples from a series of sites and provided no information on the relative abundance of the isolates per site or on their distribution within site(s). Such data are fundamental to better grasping of EPNs' persistence, distribution patterns, and effect on insect populations and to the development of predictive models for control programs.

\section{Standardization of sampling unit}

Differences in the size of the sampling unit and index of nematode dispersion used may lead to misinterpretation of the data (Been and Schomaker 2013). Valid as they are, they sometimes lack in the exactitude of the applied index. To alleviate the drawbacks of both issues, some researchers tend to apply more than one measure to the same EPNs' statistics to find out their spatial distribution patterns. For example, while Wilson et al. (2003) used spatial analysis by distance indices (SADIE), Spiridonov et al. (2007) utilized both Lloyd's index and SADIE, and Bal et al. (2017) applied two measures of spatial autocorrelation, Moran's I and Geary's $c$, as well as SADIE as indices of EPN dispersion. Yet, atypical sampling procedures of EPN may lead to erratic results. In this vein, comparing different sampling procedures, which used the same index of nematode dispersion (i.e.
SADIE), to study EPNs' distribution pattern for better perception of various results is presented (Table 1). Differences in the size or type of the sampling unit may lead to various interpretations of the resulting data (Duncan and Phillips 2009 and Been and Schomaker 2013). For example, when the size of the soil sampling unit steadily increased, the apparent EPNs' dispersion of a contagious population may be random, contagious, and finally regular (Fig. 1). Clearly, such a change in the spatial distribution pattern of EPNs in this example is dependent on the size of the sampling unit. Moreover, examining the spatial distribution of IJs-natural population assigned to four different groups based on their physiological age, Lloyds index identified group I as being the most aggregated, whereas SADIE identified group II as the most aggregated (Spiridonov et al. 2007). This is probably because group I nematodes were aggregated at a scale finer than the commonly used sampling regime. Also, Wilson et al. (2003) ascribed even distributions of EPNs measured by SADIE to the symmetrical nature of their sampled plots too. On the other hand, comparing different values for the same index of aggregation $\left(I_{\mathrm{a}}\right)$ of four different studies on EPNs' distributions (Table 1), using different sampling units in various regions is problematic. That is because the difference in volume/area of the sampling units can likely influence the resulting distribution patterns of EPNs. To name but a few, this unit was a 20-cm-diameter borer/sampler and separated into $2.5-\mathrm{cm}$ layers in Holland (Taylor 1999), a $2 \times 15 \mathrm{~cm}$ deep core in New Jersey, USA (Wilson et al. 2003), $5 \times 5 \times 5$ or $10 \mathrm{~cm}$ deep using a square auger at Merelbeke, Belgium (Spiridonov et al. 2007), cylindrical bait traps, made of 24-mesh stainless steel screen approximately $3 \mathrm{~cm}$ in diameter and $10 \mathrm{~cm}$ tall in Ohio, USA (Bal et al. 2017), and ca $30 \mathrm{~cm}$ diameter to $25 \mathrm{~cm}$ deep using a shovel in El-Beheira governorate, Egypt (Abd-Elgawad 2014). Valid as they are, they lack in the

Table 1 Comparison of index of aggregation $\left(I_{a}\right)$ (the observed value of distance to regularity/the mean randomized value (Perry 1995)) values of four different studies on entomopathogenic nematode distributions using different approaches in various regions

\begin{tabular}{|c|c|c|c|c|}
\hline EPN studied population & Form of measured EPNs & la value & Comments (location) & Reference \\
\hline $\begin{array}{l}\text { Heterorhabditis bacteriophora- } \\
\text { infective stage juveniles (IJs) } \\
\text { applied uniformly, in one or nine } \\
\text { patches on Kentucky bluegrass }\end{array}$ & $\begin{array}{l}\text { EPN-infected Galleria } \\
\text { mellonella larvae over time }\end{array}$ & $\begin{array}{l}\text { All mean values were less than } \\
\text { one but differed }(P \leq 0.05) \text { until } \\
20 \text { weeks, no more, after EPN } \\
\text { application }\end{array}$ & $\begin{array}{l}\text { The values suggest a more even } \\
\text { distribution than a random one } \\
\text { (New Jersey/USA) }\end{array}$ & $\begin{array}{l}\text { Wilson et al. } \\
2003\end{array}$ \\
\hline $\begin{array}{l}\text { Natural populations of } \\
\text { Steinernema feltiae and S. affine } \\
\text { in grassland plots }\end{array}$ & $\begin{array}{l}\text { IJs assigned to one of } 4 \\
\text { groups of increasing } \\
\text { physiological age }\end{array}$ & $\begin{array}{l}\text { The values ranged } 1.27-1.45 \text { with } \\
\text { group II as the most aggregated } \\
\text { one }\end{array}$ & $\begin{array}{l}\text { All values indicate aggregated } \\
\text { distribution (Merelbeke/Belgium) }\end{array}$ & $\begin{array}{l}\text { Spiridonov } \\
\text { et al. } 2007\end{array}$ \\
\hline $\begin{array}{l}\text { H. bacteriophora- or S. } \\
\text { carpocapsae-infected G. } \\
\text { mellonella larvae applied within } \\
24 \text { h of initial IJ emergence to } \\
\text { cultivated fields and adjoining } \\
\text { grassy border plots }\end{array}$ & $\begin{array}{l}\text { H. bacteriophora and S. } \\
\text { carpocapsae-IJs recovered } \\
\text { from G. mellonella larvae } \\
\text { baits applied several times } \\
\text { after the cadavers }\end{array}$ & $\begin{array}{l}\text { Range }<1 \text { to }>2 \text {. Mean values } \\
\text { differed between EPN species in } \\
\text { bait traps and between soil } \\
\text { management regimes at } 48 \mathrm{~h} \\
\text { and } 16 \text { days after placing the } \\
\text { cadavers, respectively }\end{array}$ & $\begin{array}{l}\text { Spatial distributions after } \\
\text { dispersing from a grassy border } \\
\text { into the adjacent cultivated field } \\
\text { plots were more aggregated for } \\
\text { H. bacteriophora than for S. } \\
\text { carpocapsae (Ohio/USA) }\end{array}$ & $\begin{array}{l}\text { Bal et al. } \\
2017\end{array}$ \\
\hline $\begin{array}{l}\text { Natural populations of } \mathrm{H} \text {. indica } \\
\text { in citrus and mango grove }\end{array}$ & $\begin{array}{l}\text { EPN-infected G. mellonella } \\
\text { larvae }\end{array}$ & 0.913 & $\begin{array}{l}l_{a} \text { refers to even distribution } \\
\text { (Giza/Egypt) }\end{array}$ & $\begin{array}{l}\text { Abd-Elgawad } \\
\text { (unpublished) }\end{array}$ \\
\hline
\end{tabular}




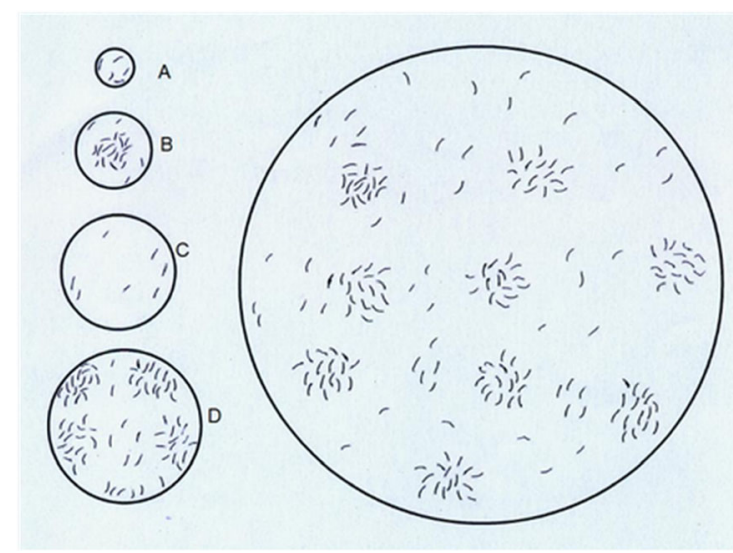

Fig. 1 Four quadrat sizes (A, B, C, D) and a contagious distribution with regularly distributed clumps of entomopathogenic nematodes

standardization of the applied sampler which could lead to erratic results (Fig. 1). Therefore, standard sampling procedure is recommended for objective and more reliable comparison among EPNs' distribution patterns. Clearly, if such an area of the sampling unit is much larger or much smaller than the average size of IJ clumps and their aggregations are regularly or randomly distributed, then their population pattern is apparently random; factual non-randomness is not detected (Fig. 1). However, relatively small samples, with the fine scale (e.g., $5 \times 5 \mathrm{~cm}$; Spiridonov 2007) can often detect nonrandomness, especially if there are not a few IJs in each clump. Eventually, sound conception of the temporal and spatial distribution of EPNs is essential for determining the role of these biocontrol agents in soil communities and ultimately for their use in suppression of pest insect populations.

\section{Establishing population modeling of EPNs}

Application of EPNs in relevant settings should be statistically investigated for modeling better pest control efficacy (Abd-Elgawad, 2017a). Modeling designation may integrate theoretical and empirical approaches for optimal application strategies of EPNs through iteration, focusing on the fate of metapopulations against economic and host insect pests. The models of previous releases will guide subsequent application strategies via providing insight into what aspects of the nematodes and the environment are the strongest drivers of persistence and efficacy (e.g., Wilson et al. 2003; Wilson and Gaugler 2004; Georgis et al. 2006; Lacey and Georgis 2012 and Campos-Herrera et al. 2019). Specific pairings between EPNs and the targeted species of insect pests should be further considered at the fine scale of host and EPNs' ecology, biology, and phenology for best matching. Since there is still little information about accuracy and precision of population density estimation, their inclusion in the predicting models may positively contribute to the broad issue of assessing infected insect hosts. Improving optimum sample size of nematode-infected G. mellonella larvae (Table 2) via iteration was suggested (Abd-Elgawad 2016). The greater the distance between the number of samples before and after iteration, the less accurate the result of the equation without iteration becomes.

\section{Advancing genetic improvement of EPNs}

Genetic improvement bodes well for the future of biocontrol using EPNs. Although successful transgenic methods have been applied in EPNs (Hashmi et al. 1998 and Vellai et al. 1999), they remain few and have not been followed up by more recent studies. Genetic improvement of EPNs via selection will continue to be important; however, transgenic organisms have become more common and they allow for reforms that simply are not possible with conventional methods (Baiocchi et al. 2017). The advances that have been made and the continued development of molecular tools should be used to address difficult applied and fundamental questions. For example, there is a crucial question of the stability of selected beneficial traits such as tolerance to desiccation and high temperature. In Heterorhabditis nematodes, the trait stabilization can be achieved by creation of inbred lines in liquid culture (Anbesse et al. 2013), which should be further developed and exploited. Further fundamental research in the field of the genetic architecture of key traits, such as infectivity, stress tolerance, and reproduction, is needed (Půža et al. 2016). Bai et al. (2013) stressed the possibility of determining genes from the whole genome of EPNs and their mutualistic bacteria that are being expressed, in order to detect those that are involved in a particular process and target them through genetic engineering methods. Yet, we lack markers to follow transfer or enhancement/degradation of traits and to identify "beneficial genes" that can be transferred between populations (Glazer 2015). Such unknown or underexplored issues need to be adequately addressed using skills and creativity of molecular biologists.

\section{Awareness-raising of EPNs' techniques and commercial applications}

Improvement programs should also cover various facets of awareness-raising of farmers and extensions of EPNs as bio-insecticides. Hence, such programs should include information days, targeting farmers and extensions to transfer knowledge, technologies, and methodologies in terms of EPN-related issues and results obtained hitherto. These events should be held at the fields where demonstration trials are found aiming at informing (via broad and deep training) farmers and extension officers about the importance, mode of action, application, and 
Table 2 Exact figures from Microsoft Excel Worksheet used to calculate the sample size before (Student's $t=2$ ) and after iteration for heterorhabditid nematode-infected Galleria mellonella larvae

\begin{tabular}{|c|c|c|c|c|c|c|c|c|}
\hline Case & $E$ & $a$ & $\bar{x}$ & $B$ & $n$ & $T$ & $t^{2}$ & $n^{+}$ \\
\hline \multirow[t]{3}{*}{1} & 0.2 & 1.2 & 4 & 0.9044 & 6.569076632 & 2 & 4 & 26.27630653 \\
\hline & 0.2 & 1.2 & 4 & 0.9044 & 6.569076632 & 2.06 & 4.2436 & 27.8765336 \\
\hline & 0.2 & 1.2 & 4 & 0.9044 & 6.569076632 & 2.052 & 4.210704 & 27.66043725 \\
\hline \multirow[t]{3}{*}{2} & 0.1 & 1.2 & 4 & 0.9044 & 26.27631 & 2 & 4 & 105.1052 \\
\hline & 0.1 & 1.2 & 4 & 0.9044 & 26.27631 & 1.983 & 3.932289 & 103.3260311 \\
\hline & 0.1 & 1.2 & 4 & 0.9044 & 26.27631 & 1.984 & 3.936256 & 103.4302692 \\
\hline \multirow[t]{3}{*}{3} & 0.1 & 1.2 & 1 & 0.9044 & 120 & 2 & 4 & 480 \\
\hline & 0.1 & 1.2 & 1 & 0.9044 & 120 & 1.965 & 3.861225 & 463.347 \\
\hline & 0.1 & 1.2 & 1 & 0.9044 & 120 & 1.965 & 3.861225 & 463.347 \\
\hline \multirow[t]{3}{*}{4} & 0.1 & 1.2 & 2 & 0.9044 & 56.15297662 & 2 & 4 & 224.6119065 \\
\hline & 0.1 & 1.2 & 2 & 0.9044 & 56.15297662 & 1.971 & 3.884841 & 218.1453859 \\
\hline & 0.1 & 1.2 & 2 & 0.9044 & 56.15297662 & 1.97095632 & 3.884668815 & 218.1357172 \\
\hline \multirow[t]{3}{*}{5} & 0.1 & 1.2 & 3 & 0.9044 & 36.01199651 & 2 & 4 & 144.047986 \\
\hline & 0.1 & 1.2 & 3 & 0.9044 & 36.01199651 & 1.97669220 & 3.907312 & 140.7101 \\
\hline & 0.1 & 1.2 & 3 & 0.9044 & 36.01199651 & 1.97705370 & 3.908741 & 140.7616 \\
\hline \multirow[t]{3}{*}{6} & 0.05 & 1.2 & 13 & 0.9044 & 28.89382 & 2 & 4 & 115.5753 \\
\hline & 0.05 & 1.2 & 13 & 0.9044 & 28.89382 & 1.9808 & 3.92356864 & 113.3669 \\
\hline & 0.05 & 1.2 & 13 & 0.9044 & 28.89382 & 1.9814 & 3.92594596 & 113.4356 \\
\hline
\end{tabular}

Estimates are calculated using the equations: $n=(1 / E)^{2} a \bar{x}^{b-2}$ or $n^{+}=\left(t_{a[n-1]} / D\right)^{2} a \bar{x}^{b-2}$ where $n$ or $n^{+}$is the sample size, $E$ the standard error to mean ratio, $D$ the ratio of the half-width of the confidence interval to the mean of the samples, $a$ and $b$ are the parameters of Taylor's Power Law, $\bar{x}$ the arithmetic mean of the heterorhabditid nematode-infected G. mellonella larval population in a soil sample, $t_{a}[n-1]$ is the appropriate Student's $t$ value for confidence limits of $1-a$ and $n$ - 1 degrees of freedom (http://www.danielsoper.com/statcalc3/calc.aspx?id = 10) for the insect population (Abd-Elgawad 2014)

impact of EPNs on insect pests, crops, and soil health. During information days and training, principles and main components of effective integrated pest control programs, such as prophylactic cultural practices, crop rotations, and other pest control techniques/measures, should be discussed. For example, an alternative approach to common EPNs' production that may contribute to market expansion would be developing growerbased or cooperative level "do-it-yourself" ventures (Shapiro-Ilan et al. 2014a). Illustrations and guidelines of modern technologies to manage important insect pests should be presented. Dissemination of knowledge and updated advances in EPNs' technology/methodology should be transferred to both farmers and extension officers during information days. Questionnaires should also be compiled to evaluate the acceptance of participants of EPN evaluated in their gardens/fields.

Relevant pamphlets containing such information should be circulated. Because of the importance of mass media in the enlightenment and providing culture to the public about entomopathogenic nematode production, storage, and application, constructing more international internet websites may be established via both relevant programs and EPNs' producing companies with an end in view to increase the number of people interested in the activity and goals of biological control against insect pests hoping to reap clean and safe agricultural products for man and environment. Moreover, stakeholders should know that EPNs work more slowly, requiring different, more complicated criteria such as yield for measuring effectiveness, contrary to chemical insecticides that are based on quick knockdown for pest control. It is also worth considering whether anything less than perfect produce is permissible (Gaugler, 1997). Eventually, this sort of mindset change is essential for encouraging broader use of bio-pesticides.

\section{Conclusions}

Required but less known roles to optimize research in the nematode realm should further be addressed for advancing EPNs as bio-pesticides. These may include extending functional sampling in addition to wide EPNs' surveys for coordination in search of new species/strains. Adequate and standardized sampling should be practiced to avoid erratic results and offer measurable comparisons. Genetic improvement of EPNs should address non-stability of selected beneficial traits and find out markers of beneficial genes. Various aspects of awareness-raising for stakeholders in EPNs' research and applications should be better communicated.

\section{Abbreviations}

EPNs: Entomopathogenic nematodes; IJs: Infective stage juveniles;

IPM: integrated pest management; SADIE: Spatial analysis by distance indices 


\section{Acknowledgements}

This study was supported in part by the US-Egypt Project cycle 17 (no. 172) entitled "Preparing and evaluating IPM tactics for increasing strawberry and citrus production." This article is derived from the Subject Data funded in part by NAS and USAID, and that any opinions, findings, conclusions, or recommendations expressed in it are those of the authors alone and do not necessarily reflect the views of USAID or NAS. Facilities offered by The National Research Centre are appreciated.

\section{Author's contributions}

The author has developed and implemented this review article and subsequently written it. The author read and approved the final manuscript.

\section{Funding}

Financial support made by US-Egypt Project fund for Project cycle 17 (no. 172) and National Research Centre, Egypt, is gratefully acknowledged.

\section{Availability of data and materials}

The datasets used and/or analyzed during the current study are available from the corresponding author on reasonable request.

\section{Ethics approval and consent to participate}

Not applicable

\section{Consent for publication}

Not applicable

\section{Competing interests}

The author declares that he has no competing interests.

Received: 8 August 2019 Accepted: 14 October 2019

Published online: 25 November 2019

\section{References}

Abd-Elgawad MMM (2014) Spatial patterns of Tuta absoluta and heterorhabditid nematodes. Russian J Nematol 22:89-100

Abd-Elgawad MMM (2016) Use of Taylor's power law parameters in nematode sampling. Int J Pharm Tech Res 9(12):999-1004

Abd-Elgawad MMM (2017a) Comments on the economic use of entomopathogenic nematodes against insect pests. Bull NRC 41(1):66-84

Abd-Elgawad MMM (2017b) Status of entomopathogenic nematodes in integrated pest management strategies in Egypt. In: Abd-Elgawad MMM, Askary TH, Coupland J (eds) Biocontrol agents: entomopathogenic and slug parasitic nematodes. CAB Int, Wallingford, pp 473-501

Abd-Elgawad MMM (2017c) Toxic secretions of Photorhabdus and their efficacy against crop insect pests. In: Abd-Elgawad MMM, Askary TH, Coupland J (eds) Biocontrol agents: entomopathogenic and slug parasitic nematodes. CAB Int, Wallingford, pp 231-260

Abd-Elgawad MMM, Askary TH, Coupland J (eds) (2017) Biocontrol agents: entomopathogenic and slug parasitic nematodes. CAB Int, Wallingford, UK

Anbesse S, Sumaya NH, Dörfler AV, Strauch O, Ehlers RU (2013) Stabilization of heat tolerance traits in Heterorhabditis bacteriophora through selective breeding and creation of inbred lines in liquid culture. BioControl 58:85-93

Arthurs S, Heinz KM, Prasifka JR (2004) An analysis of using entomopathogenic nematodes against above-ground pests. Bull Entomolog Res 94:297-306

Askary TH, Nermut J, Ahmad MJ, Ganai MA (2017) Future thrusts in expanding the use of entomopathogenic and slug parasitic nematodes in agriculture. In: Abd-Elgawad MMM, Askary TH, Coupland J (eds) Biocontrol agents: entomopathogenic and slug parasitic nematodes. CAB Int, Wallingford, pp 620-627

Bai X, Adams BJ, Ciche TA, Clifton S, Gaugler R, Kim KS, Spieth J, Sternberg PW, Wilson RK, Grewal PS (2013) A lover and a fighter: the genome sequence of an entomopathogenic nematode Heterorhabditis bacteriophora. PLoS One. 8(7):e69618. https://doi.org/10.1371/journal.pone.0069618

Baiocchi T, Abd-Elgawad MMM, Dillman AR (2017) Genetic improvement of entomopathogenic nematodes for enhanced biological control. In: AbdElgawad MMM, Askary TH, Coupland J (eds) Biocontrol agents: entomopathogenic and slug parasitic nematodes. CAB Int, Wallingford, pp 505-517
Bajc N, Držaj U, Trdan S, Laznik Ž (2017) Compatibility of acaricides with entomopathogenic nematodes (Steinernema and Heterorhabditis). Nematology 19:891-898

Bal HK, Acosta N, Cheng Z, Grewal PS, Hoy CW (2017) Effect of habitat and soil management on dispersal and distribution patterns of entomopathogenic nematodes. Appl Soil Ecol 121:48-59

Been TH, Schomaker CH (2013) Distribution patterns and sampling. In: Perry RN, Moens M (eds) Plant nematology, 2nd edn. CAB Int, Wallingford, pp 331-358

Campos-Herrera R (ed) (2015) Nematode pathogenesis of insects and other pests: ecology and applied technologies for sustainable plant and crop protection. Springer Int Publishing, Zurich, Switzerland

Campos-Herrera R, Stuart RJ, Pathak E, El-Borai FE, Duncan LW (2019) Temporal patterns of entomopathogenic nematodes in Florida citrus orchards: evidence of natural regulation by microorganisms and nematode competitors. Soil Biol Biochem 128:193-204

Da Silva OS, Prado GR, Da Silva JLR, Silva CE, Da Costa M, Heermann R (2013) Ora toxicity of Photorhabdus luminescens and Xenorhabdus nematophila (Enterobacteriaceae) against Aedes aegypti (Diptera: Culicidae). Parasitol Res 112:2891-2896

Duncan LW, Phillips MS (2009) Sampling root-knot nematodes. In: Perry RN, Moens M, Starr JL (eds) Root-knot nematodes. CAB Int, St. Albans, UK, pp 275-300

Dziegielewska M, Skwiercz A (2018) The influence of selected abiotic factors on the occurrence of entomopathogenic nematodes (Steinernematidae, Heterorhabditidae) in soil. Polish J Soil Sci LI/1: 11-21. DOl: https://doi.org/10. 17951/pjss/2018.51.1.11

El-Sadawy HA, Elnamaky AH, Elsayed EH, Abdelmaguid BB, Ayaad TH, Ahmed AM (2018) Silver nanoparticles enhance the larvicidal toxicity of Photorhabdus and Xenorhabdus bacterial toxins: an approach to control the filarial vector, Culex pipiens. Tropic Biomed 35(2):392-407

El-Sadawy HA, El-Shazly A, El-Khateeb MM (2008a) Histopathological studies of hard tick Hyalomma dromedarii infected by entomopathogenic nematodes. J. Entomol 5(2):62-76

El-Sadawy HA, Zayed AA, El-Shazly A (2008b) Characterization of midgut and salivary gland proteins of Hyalomma dromedarii females controlled by entomopathogenic nematodes. Pakistan J Biol Sci 11(4):508-516

Ffrench-Constant RH, Dowling A, Waterfield NR (2007) Insecticidal toxins from Photorhabdus bacteria and their potential use in agriculture. Toxicon 49:436-451

Gaugler R (1997) Alternative paradigms for commercializing biopesticides. Phytoparasitica 25(3):179-181

Georgis R, Koppenhöfer AM, Lacey LA, Belair G, Duncan LW, Grewal PS, Samish M, Tan L, Torr P, van Tol RWHM (2006) Successes and failures in the use of parasitic nematodes for pest control. Biol Cont 38:103-123

Glazer I (2015) Improvement of entomopathogenic nematodes: a genetic approach. In: Campos-Herrera R (ed) Nematode pathogenesis of insects and other pests: ecology and applied technologies for sustainable plant and crop protection. Springer Int Publishing, Zurich, Switzerland, pp 29-55

Hashmi S, Hashmi G, Glazer I, Gaugler R (1998) Thermal response of Heterorhabditis bacteriophora transformed with the Caenorhabditis elegans hsp70 encoding gene. J Exper Zool 281:164-170

Heve WK, El-Borai FE, Johnson EG, Carrillo D, Crow WT, Duncan LW (2018) Responses of Anastrepha suspensa, Diachasmimorpha longicaudata, and sensitivity of guava production to Heterorhabditis bacteriophora in fruit fly integrated pest management. J Nematol 50(3):261-272

Hussaini SS (2017) Entomopathogenic nematodes: ecology, diversity and geographical distribution. In: Abd-Elgawad MMM, Askary TH, Coupland J (eds) Biocontrol agents: entomopathogenic and slug parasitic nematodes. CAB Int, Wallingford, pp 88-142

Kaya H, Gaugler R (1993) Entomopathogenic nematodes. Ann Rev Entomol 38: $181-206$

Koppenhöfer AM, Grewal PS (2005) Compatibility and interactions with agrochemicals and other biocontrol agents. In: Grewal PS, Ehlers R-U, Shapiro-llan D (eds) Nematodes as biocontrol agents. CAB Int, Wallingford, pp 363-381

Lacey LA, Georgis R (2012) Entomopathogenic nematodes for control of insect pests above and below ground with comments on commercial production. J Nematol 44:218-225

Laznik Ž, Trdan S (2014) The influence of insecticides on the viability of entomopathogenic nematodes (Rhabditida: Steinernematidae and Heterorhabditidae) under laboratory conditions. Pest Manage Sci 70(5): 784-789 
Laznik $\check{Z}$, Trdan S (2017) Influence of herbicides on the viability of entomopathogenic nematodes (Rhabditida: Steinernematidae and Heterorhabditidae). Int J Pest Manage 63(2):105-111

Laznik $\breve{Z}$, Vidrih M, Trdan S (2012) The effects of different fungicides on the viability of entomopathogenic nematodes Steinernema feltiae (Filipjev), $S$. carpocapsae Weiser, and Heterorhabditis downesi Stock, Griffin \& Burnell (Nematoda: Rhabditida) under laboratory condition. Chilean J Agric Res 72(1): 62-67

Lulamba TE, Green E, Serepa-Dlamini MH (2018) Entomopathogenic nematodes, potential industrial pest control agents: a South African perspective. J Entomol Nematol 11(1):1-12

Nguyen KB, Smart GC Jr (1990) Steinernema scapterisci n. sp. (Rhabditida: Steinernematidae). J Nematol 22:187-199

Perry JN (1995) Spatial analysis by distance indices. J Anim Ecol 64:303-314

Půža V, Mráček Z, Nermu J (2016) Novelties in pest control by entomopathogenic and mollusc-parasitic nematodes. In: Gill HK, Goyal G (eds) Integrated pest management (IPM): environmentally sound pest management. Intech Open. https://doi.org/10.5772/64578, pp 71-102

Shapiro-llan DI, Bock CH, Hotchkiss MW (2014b) Suppression of pecan and peach pathogens on different substrates using Xenorhabdus bovienii and Photorhabdus luminescens. Biol Cont 77:1-6

Shapiro-llan DI, Han R, Qiu X (2014a) Production of entomopathogenic nematodes. In: Morales-Ramos J, Rojas G, Shapiro-llan DI (eds) Mass production of beneficial organisms: invertebrates and entomopathogens. Academic Press, San Diego, pp 321-356

Shapiro-llan DI, Hazir S, Glazer I (2017) Basic and applied research: entomopathogenic nematodes. In: Lacey LA (ed) Microbial agents for control of insect pests: from discovery to commercial development and use. Academic Press, Amsterdam, pp 91-105

Shehata IE, Hammam MMA, El-Borai FE, Duncan LW, Abd-Elgawad MMM (2019) Comparison of virulence, reproductive potential, and persistence among local Heterorhabditis indica populations for the control of Temnorhynchus baal (Reiche \& Saulcy) (Coleoptera: Scarabaeidae) in Egypt. Egypt J Biol Pest Cont 29:32 https://doi.org/10.1186/s41938-019-0137-5

Spiridonov SE, Moens M, Wilson MJ (2007) Fine scale spatial distributions of two entomopathogenic nematodes in a grassland soil. Appl Soil Ecol 37:192-201

Stevens G, Lewis E (2017) Status of entomopathogenic nematodes in integrated pest management strategies in the USA. In: Abd-Elgawad MMM, Askary TH, Coupland J (eds) Biocontrol agents: entomopathogenic and slug parasitic nematodes. CAB Int, Wallingford, pp 289-311

Stuart RJ, Barbercheck ME, Grewal PS (2015) Entomopathogenic nematodes in the soil environment: distributions, interactions and the influence of biotic and abiotic factors. In: Campos-Herrera R (ed) Nematode pathogenesis of insects and other pests: ecology and applied technologies for sustainable plant and crop protection. Springer Int Publishing, Zurich, Switzerland, pp $97-138$

Stuart RJ, Barbercheck ME, Grewal PS, Taylor RAJ, Hoy CW (2006) Population biology of entomopathogenic nematodes: concepts, issues, and models. Biol Cont 38:80-102

Taylor RAJ (1999) Sampling entomopathogenic nematodes and measuring their spatial distribution. Pp. 43-60 In: Gwynn RL, Smits PH, Griffin C, Ehlers R-U, Boemare N, Masson J-P (eds) Application and persistence of entomopathogenic nematodes. European Commission (EUR 18873 EN).

Vellai T, Molnar A, Laktos L, Banfalvi Z, Fodor A, Saringer G (1999) Transgenic nematodes carrying a cloned stress resistance gene from yeast. In: Glazer I, Richardson P, Boemare N, Coudert F (eds) Survival of entomopathogenic nematodes. Office for Official Publications of the European Communities, Luxembourg, pp 105-119

Wilson M, Gaugler R (2004) Factors limiting short-term persistence of entomopathogenic nematodes. J Appl Entomol 128(4):250-253

Wilson MJ, Lewis EE, Yoder F, Gaugler R (2003) Application pattern and persistence of the entomopathogenic nematode Heterorhabditis bacteriophora. Biol Cont 26:180-188

\section{Publisher's Note}

Springer Nature remains neutral with regard to jurisdictional claims in published maps and institutional affiliations.

\section{Submit your manuscript to a SpringerOpen ${ }^{\circ}$ journal and benefit from:}

- Convenient online submission

- Rigorous peer review

- Open access: articles freely available online

- High visibility within the field

- Retaining the copyright to your article

Submit your next manuscript at $\boldsymbol{\nabla}$ springeropen.com 